\title{
Glycerin and cashew and castor oils in the diets for bulls in finished in feed lot: ingestive behavior
}

\author{
Glicerina e óleos de caju e mamona nas dietas para bovinos não \\ castrados terminados em confinamento: comportamento ingestivo
}

\author{
Lorrayny Galoro da Silva ${ }^{1}$; Juliana Akamine Torrecilhas ${ }^{2}$; \\ Rodrigo Augusto Cortêz Passetti²; Mariana Garcia Ornaghi²; \\ Carlos Emanuel Eiras ${ }^{3}$; Dayane Cristina Rivaroli ${ }^{3}$; \\ Maribel Velandia Valero ${ }^{4}$; Ivanor Nunes do Prado ${ }^{5 *}$
}

\begin{abstract}
This study was carried out to evaluate partial replacing of corn ( $15 \%$ of total diet DM) and cashew and castor oils addition on ingestive behavior of Nellore bulls in feedlot. Thirty bulls of $24 \pm 2$ months old and $400 \pm 34 \mathrm{~kg}$ body weight were used. The bulls were distributed in a completely randomized design (10 bulls per treatment) and housed in collective pens. The experimental diets were: Control - CON; Glycerine - GLY and Glycerine + Functional oils. The observation scales did not influence time spent eating, ruminating or resting, as well as, the total number of chewing; however the number of periods and the time period for such activities differed among the scales time. There was no difference for the number of observations turns and number of observations per turn for analyzed variables. Glycerine inclusion in the diets caused a decrease on ruminating time and an increase in resting time. The numbers for both eating and resting periods, and time per resting period differed among diets, however, the number for ruminating period, eating time and rumination period were similar among diets. Both glycerine and functional oils inclusion in the diets increased the number of ruminated bolus per day, number of chewed per day and total chewing time for cattle.
\end{abstract}

Key words: Additives, biodiesel, co-product, ethology, plant extracts, ruminant

\section{Resumo}

Este estudo foi realizado para avaliar a substituição parcial do milho (15\% da MS total da dieta) e adição de óleos de caju e mamona sobre o comportamento ingestivo de Nelore machos, confinados. Trinta bovinos de $24 \pm 2$ meses de idade e $400 \pm 34 \mathrm{~kg}$ de peso corporal foram usados. Os animais foram distribuídos em um modelo estatístico inteiramente casualizado (10 animais por tratamento) e estabulados em baias coletivas. As dietas experimentais foram: Controle - CON; Glicerina - GLI e GOF - Glicerina + óleos funcionais. As escalas de observações não influenciaram o tempo de ingestão, ruminação e ócio, assim como o número total de mastigação; entretanto, o número de período e o tempo de período de cada atividade diferiram entre os tempos de escalas. Não houve diferença para os turnos

\footnotetext{
${ }^{1}$ M.e em Zootecnia, Universidade Estadual de Marinagá, UEM, Maringá, PR, Brasil. E-mail: lorraynyg@hotmail.com

${ }^{2}$ Discentes de Mestrado em Zootecnia, UEM, Maringá, PR, Brasil. E-mail: ju_akami@hotmail.com; racpassetti@gmail.com; marianaornaghi@hotmail.com

${ }^{3}$ Discentes de Doutorado em Zootecnia, UEM, Maringá, PR, Brasil. E-mail: carlos.eiras@hotmail.com; dayrivaroli@hotmail.com

${ }^{4}$ Pós-Doutoranda em Zootecnia, UEM, Maringá, PR, Brasil. E-mail: maribelvelandia@hotmail.com

${ }^{5}$ Prof. Titular, UEM, Maringá, PR, Brasil. Pesquisador 1A CNPq. E-mail: inprado@uem.br

* Author for correspondence
} 
de observações e número de observações por turno para as variáveis analisadas. A inclusão de glicerina na dieta reduziu o tempo de ruminação e aumentou o tempo de ócio. O número de período tanto de ingestão como de ócio, e o tempo de ócio diferiram entre as dietas. No entanto, o número de período de ruminação, tempo de ingestão e período de ruminação foi similar entre as dietas. A inclusão de glicerina e óleos funcionais na dieta aumentou o número de bolos ruminados por dia, número de mastigação por dia e tempo total de mastigação dos bovinos.

Palavras-chave: Aditivos, biodiesel, co-produto, etologia, extrato de planta, ruminantes

\section{Introduction}

One of the biggest challenges faced by the livestock industry in developing countries is the general increasing demand by foreign consumers for high-quality, healthy products with enhanced safety from food production systems with improved environmental and carbon emissions (HOCQUETTE et al., 2012).

The biodiesel industry has rapidly expanded worldwide through the past few years (FAPRI, 2012). In 2011, the biodiesel industry produced approximately 2 billion L of glycerine worldwide, where the Brazilian market produced approximately 2.6 million L (FAPRI, 2012). Research has demonstrated that glycerine is an excellent energy source and can partially replace corn grain in ruminant diets (LEE et al., 2011; EIRAS et al., in press). Glycerol is involved in the process of gluconeogenesis (KREHBIEL, 2008), and improves the synthesis of glucose in the liver (CHUNG et al., 2007), providing energy for cellular metabolism (GOFF; HORST, 2001) also improving fat deposition (MACH; BACH; DEVANT, 2009).

For cattle finishing system with high-energy requirements, it is necessary to increase the use of grains and cereals (KAZAMA et al., 2008; ITO et al., 2010). When ruminants are fed forages, the ruminal $\mathrm{pH}$ is close to neutral, but when finishing with rations containing large amounts of cereal grain, the ruminal $\mathrm{pH}$ can decrease drastically (VAN SOEST, 1994). Rumen acidosis is often associated with an increase in lactate, a much stronger acid than the typical volatile fatty acids found in the rumen. To modulate rumen fermentation, diets are supplemented with ionophores or antibiotics (RUSSELL; STROBEL,
1989). However, no animal-based food products containing such substances have entered or been produced in Europe since January 2006, according to the European Union legislation published in the Official Journal of the European Union (2003). Thus, it is necessary research for natural alternatives to ionophores or antibiotics in the diets for ruminants (CALSAMIGLIA et al., 2007; BENCHAAR et al., 2008).

Plant oils may also be able to replace the use of antibiotics in ruminant nutrition once many plants produce secondary metabolites (BURT, 2004; BENCHAAR et al., 2008; ZHANG et al., 2010). The functional oils contain secondary metabolites (terpenoids, phenolic compounds and others) that show antimicrobial activity toward Grampositive and Gram-negative bacteria (BURT, 2004; BENCHAAR et al., 2008).

Castor oil contains a high percentage of ricinoleic acid (MORRIS, 1967; NAUGHTON, 2000) and cashews contain a high percentage of anacardic acid and a lower proportion of cardol and cardanol (TREVISAN et al., 2006); which has antimicrobial properties (NOVAK; CLARK; DUPUY, 1961; SHIN; KIM; KANG, 2004).

On the other hand, factors that regulate dry matter intake by ruminants are complex and not fully understood. Nevertheless, accurate feed intake estimates are vital to predicting rate of animals gain. Previous research has established relationships between dietary energy concentration and dry matter intake by beef cattle, based on the concept that the consumption of less digestible, low-energy often high-fiber diets is controlled by physical factors such as rumen fill and digest passage, whereas the 
consumption of highly digestible, high-energy often low-fiber, high-concentrate diets is controlled by the animal's energy demands and by metabolic factors (NRC, 2000). The ingestive behavior is related to the intake, obtaining data to improve animal performance by feed intake (ALBRIGHT, 1993). Animal performance is mainly influenced by dry matter intake that can be affected by the amount of fiber (MISSIO et al., 2010) and energy content in the diet (FREITAS et al., 2010). Feed intake of diet with high concentration of NDF, increases the number and chewing duration and ruminating duration due to fill the rumen-reticulum (DADO; ALLEN, 1995). According to Van Soest (1994) ruminating duration is influenced by the nature of the diet and seems to be proportional to the cell wall content of forages. According to Forbes (1988) the ruminants can modify in part the ingestive behavior minimizing the effects of unfavorable dietary conditions, reaching their nutritional requirements for maintenance and growth. Bürger et al. (2000) found that period feeding duration of animal finished in feed-lot may vary from one to six hours, depending directly on the energy levels in the diet. The decrease of NDF caused by increased levels of concentrate (energy) in the diet reduces feeding and rumination duration, providing more time to animal performance as well as improving it, the same applies to other activities that require lower energy expenditures (SOUZA et al., 2007).

This work was carried out to study the feeding behaviour of Nellore bulls finished in feedlot and fed with diets containing glycerine and cashew and castor oils.

\section{Materials and Methods}

\section{Local, animals, housing and diets}

This experiment was approved by Department of Animal Production at the State University of
Maringá (CIOMS/OMS, 1985). It was conducted at the JAE Farm in Colorado city, Paraná State, Brazil South.

Thirty crossbred Nellore bulls were used in a completely randomized design. At the start of the experimental period, the bulls weighed $400.0 \pm$ $34.1 \mathrm{~kg}$ and were $22 \pm 2$ months old and vaccinated against clostridial diseases (Aftobov ${ }^{\circledR}$ - Merial of Brazil), treated against ectoparasites, wormed (Ivermectin $^{\circledR}$ - Merial of Brazil) and weighed. Bulls were housed in collective pens with $100 \mathrm{~m}^{2}$ on ground, equipped with feeders of $60 \mathrm{~cm}$ deep and $10 \mathrm{~m}$ length and drinkers with a capacity of 250 liters of water. The intake of concentrate and corn silage were recorded daily until day 63 of the experimental period when the bulls reached a final body weight (BW) of $520.0 \pm 27.9 \mathrm{~kg}$.

The bulls were randomly assigned to 1 of 3 diets: CON - Control, GLY - replacing of corn by $15 \%$ (on a total DM) glycerine diet and GFO replacing of corn by $15 \%$ (on a total DM) glycerine with functional oils addition (3 grams/animal/day). The concentrate used was based on corn, soybean meal, glycerine, urea, limestone and mineral salt. Diets provided showed the ratio of $50 \%$ roughage (corn silage) and 50\% concentrate (Table 1).

All the diets were formulated to be isonitrogenous and isoenergertics. Both chemical compositions of ingredients and diets are presented in table 2 . The bulls were fed twice a day at 08:00 and 15:00 h. The diets were weighed daily so that the refusals represented $5 \%$ of the total. The diet formulation and quantity supplied were designed to provide a weight gain of $1.3 \mathrm{~kg} /$ day, according to $(\mathrm{NRC}$, 2000) the recommendations.

Glycerine was produced in a soy-diesel facility, while chemical composition was determined at the Institute of Technology of Paraná (TECPAR, Table 3). 
Table 1. Composition (\% DM) of the diets.

\begin{tabular}{lccc}
\hline Ingredients & $\mathrm{CON}^{1}$ & $\mathrm{GLY}^{2}$ & $\mathrm{GFO}^{3}$ \\
\hline Corn silage & 49.9 & 49.9 & 49.9 \\
Corn cracked & 40.1 & 24.6 & 24.6 \\
Soybean meal & 8.93 & 8.93 & 8.93 \\
Glycerine & & 15.0 & 15.0 \\
Limestone & 0.50 & 0.50 & 0.50 \\
Mineral salt & 0.50 & 0.50 & 0.50 \\
Urea & 0.10 & 0.54 & 0.54 \\
Oils & & & 0.04 \\
\hline
\end{tabular}

${ }^{1}$ Control, ${ }^{2}$ Glycerine, ${ }^{3}$ Glycerine + Functional oils.

Source: Elaboration of the authors.

Table 2. Ingredients and composition ( $\% \mathrm{DM})$ of the diets.

\begin{tabular}{lccccccccccc}
\hline Ingredients & $\mathrm{DM}^{1}$ & $\mathrm{OM}^{2}$ & $\mathrm{Ash}$ & $\mathrm{CP}^{3}$ & $\mathrm{EE}^{4}$ & $\mathrm{TDN}^{5}$ & $\mathrm{NDF}^{6}$ & $\mathrm{ADF}^{7}$ & $\mathrm{TC}^{8}$ & $\mathrm{NFC}^{9}$ & $\mathrm{FC}^{10}$ \\
\hline Corn silage & 31.5 & 95.5 & 4.41 & 7.78 & 2.88 & 56.0 & 52.4 & 29.4 & 84.9 & 32.5 & 52.5 \\
Corn cracked & 88.6 & 98.6 & 1.36 & 8.40 & 4.03 & 90.0 & 9.63 & 4.08 & 86.2 & 76.8 & 9.63 \\
Soybean meal & 89.3 & 92.8 & 7.24 & 47.3 & 1.13 & 81.5 & 13.9 & 9.86 & 44.3 & 30.4 & 13.9 \\
Glycerine & 88.0 & 94.5 & 5.50 & 1.00 & 10.0 & 90.0 & & & & & \\
Limestone & 99.2 & 2.67 & 97.3 & & & & & & & & \\
Mineral salt & & 99.0 & 2.00 & 98.0 & & & & & & & \\
Urea & 97.5 & & 100 & 282 & & & & & & & \\
Oils & 98.0 & 98.0 & 2.00 & & & & & & & & \\
\hline Diets & & & & & & & & & & & \\
\hline CON $^{12}$ & 46.4 & 94.6 & 4.43 & 11.6 & 3.12 & 70.4 & 31.2 & 17.1 & 80.1 & 49.0 & 31.1 \\
$\mathrm{GLY}^{13}$ & 46.4 & 93.6 & 5.47 & 10.7 & 3.98 & 70.0 & 29.7 & 16.5 & 67.1 & 43.5 & 23.5 \\
$\mathrm{GFO}^{14}$ & 46.4 & 93.6 & 5.47 & 10.7 & 3.98 & 70.0 & 29.7 & 16.5 & 67.1 & 43.5 & 23.5 \\
\hline
\end{tabular}

${ }^{1}$ Dry matter, ${ }^{2}$ Organic matter, ${ }^{3}$ Crude protein, ${ }^{4}$ Ether extract, ${ }^{5}$ Total digestible nutriments, ${ }^{6}$ Neutral detergent fiber, ${ }^{7}$ Acid detergent fiber, ${ }^{8}$ Total carbohydrates, ${ }^{9}$ Non-fibrous carbohydrates ${ }^{10}$ Fibrous carbohydrates, ${ }^{11}$ Guarantee levels (per kg): calcium - $175 \mathrm{~g}$; phosphorus $100 \mathrm{~g}$; sodium - $114 \mathrm{~g}$; selenium - $15 \mathrm{~g}$; magnesium - $15 \mathrm{~g}$; zinc - $6.004 \mathrm{mg}$; manganese - $1.250 \mathrm{mg}$; copper - 1.875; iodine - 180 $\mathrm{mg}$; cobalt - $125 \mathrm{mg}$; selenium - $30 \mathrm{mg}$; fluorine (maximum) - $1.000 \mathrm{mg},{ }^{12}$ Control, ${ }^{13}$ Glycerin, ${ }^{14}$ Glycerine + Functional oils.

Source: Elaboration of the authors.

Table 3. Chemical composition of glycerine ${ }^{1}$.

\begin{tabular}{lc}
\hline${\text { Water, } \%^{2}}^{2}$ & 12.47 \\
Ashes, \% & 4.761 \\
Glycerol, \% & 81.3 \\
Alcohol - methanol, \% & 0.33 \\
Crude protein, \% & 0.12 \\
Fatty acids, \% & 0.13 \\
Sodium, $\mathrm{mg} / \mathrm{kg}$ & 1.1634 \\
Potassium, $\mathrm{mg} / \mathrm{kg}$ & 79.1 \\
Calcium, $\mathrm{mg} / \mathrm{kg}$ & 35.8 \\
Magnesium, $\mathrm{mg} / \mathrm{kg}$ & 16.3 \\
Phosphorus, $\mathrm{mg} / \mathrm{kg}$ & 240 \\
\hline
\end{tabular}

${ }^{1}$ TECPAR, Curitiba, Paraná, Brazil, ${ }^{2}$ Karl Fischer.

Source: Elaboration of the authors. 
The functional oils (FO) contain ricinoleic, anacardic, cardanol and cardol acids. The ricinoleic acid was obtained from castor oil (extracted from castor seed - Ricinus communis) and the anacardic, cardanol and cardol acids derived from cashew seed (Anacardium occidentale); both oils were produced in northern Brazil. Vermiculite was used for functional oils solidification. The functional oils were formulated by the Laboratory Oligo Basics Agroindustrial Ltd.

\section{Performance and feed intake}

To determine animal performance, the bulls were weighed once at the beginning of the experiment and then once every 21 days (after a fasting from solid food for a period of 16 hours).

Daily feed intake was estimated as the difference between the supplied feed and the refusals in the trough. During the collection period, samples of the supplied feed and refusals were daily collected and a representative composite sample was drafted per animal in each treatment for analysis.

\section{Samples collection}

The behavior activities were observed on 41 and 63 days of experimental period during $48 \mathrm{~h}$. To facilitate the activities, the bulls were numbered from 1 to 10 with black ink on hindquarter. During nocturne period, the facilities received artificial illumination. The bulls were adapted for artificial illumination three days before samples assessments. The data collections were carried out during 48 consecutive hours, with a record of activities in specific ethogram every five minutes; being 288 daily observations (GARY; SHERRITT; HALE, 1970). Other five scales (10, 15, 20, 25 and $30 \mathrm{~min}$.) among observations periods were carried out to evaluate the time spent in intake activities according to methodology described by Silva et al. (2006). On the same day, according to methodology described by Bürger et al. (2000) it was performed the number of chewing per bolus (NCB); how many times bolus is chewed per day after regurgitation. Likewise, time per ruminated bolus was evaluated (TRB); how much time was spent for each bolus ruminated after regurgitation. The activities were unregistered using digital chronometers.

The determinations of the number of ruminated bolus per day (NRBD) and the time of total chewing (TTC, min/day) were conducted according to methodology described by Bürger et al. (2000) and determinate by equations following:

$$
\begin{aligned}
& \mathrm{NRBD}=\mathrm{TRD} \text { (sec/day)/DRT (sec/bolus) } \\
& \mathrm{TCT}=\text { DAT (min/day) + DRT (min/day) }
\end{aligned}
$$

Where TRD, TRB and TED meaning: time of ruminating per day, time ruminating per bolus and time of eating per day, respectively.

The number of chewing per day (NCD) was calculated by equation:

$\mathrm{NCD}=$ number of chewed bolus per day $\mathrm{x}$ number of ruminated bolus per day.

For a correct number of observations per turns, the data relating the numbers of time per chewed bolus, time per ruminated bolus, the number of ruminated bolus per day and the number of chewing per day were registered during four different turn periods: morning, afternoon, night and dawn. The observations were divided in four turns: one turns (1S) from $7 \mathrm{~h} 00$ to $12 \mathrm{~h} 55$, two turns (2S) from $7 \mathrm{~h} 00$ to $18 \mathrm{~h} 55$, three turns (3S) from $7 \mathrm{~h} 00$ to $00 \mathrm{~h} 55$ ) and four turns (4S) from $7 \mathrm{~h} 00$ to $6 \mathrm{~h} 55$ ). Under the same parameters were compared four observations by bulls per turns ( $4 \mathrm{R}-\mathrm{CON}, 3 \mathrm{R}, 2 \mathrm{R}$ and $1 \mathrm{R}$; where $\mathrm{R}$ is replications).

The series of discretization by time was carried out on worksheets of data collection, with counting of discrete time (min/day) for eating (EAT), ruminating (RUT) and resting (RET), to according to Silva et al. (2006). The behavioral activities were collected by eight observers, divided into four turns who alternated every two hours (GARY; SHERRITT; HALE, 1970). 


\section{Chemical analyses}

Dry matter content of the ingredients (silage and concentrate mix) was determined by ovendrying at $105^{\circ} \mathrm{C}$ for $24 \mathrm{~h}$ (AOAC, 1998) (method 930.15). The OM content was calculated as the difference between DM and ash contents, with ash determined by combustion at $550^{\circ} \mathrm{C}$ for $5 \mathrm{~h}$ (AOAC, 1998). The NDF and ADF contents were determined using the methods described by Van Soest; Robertson and Lewis (1991) with heat stable alpha-amylase for solubilization the amylaceous compound (MERTENS, 2002) and sodium sulfite used in the NDF procedure, and expressed inclusive of residual ash. The content of $\mathrm{N}$ in the samples was determined through the Kjeldahl method (AOAC, 1998) (method 976.05). Total carbohydrates (TC) were obtained by using the following equation: $\mathrm{TC}=100-(\% \mathrm{CP}+\% \mathrm{EE}+\%$ Ash $)($ SNIFFEN et al., 1992). Non-fiber carbohydrates (NFC) were determined by the difference between $\mathrm{TC}$ and NDF. Total digestible nutrients (TDN) content of diets was obtained by the methodology descript by Kearl (1982): silage $=-17.2649+1.2120(\% \mathrm{CP})$ $+0.8352(\% \mathrm{ENN})+2.4637(\% \mathrm{EE})+0.4475(\%$
$\mathrm{CF})$; energetic foods $=40.2625+0.1969(\% \mathrm{CP})$ $+0.4228(\% \mathrm{ENN})+1.1903(\% \mathrm{EE})+0.1379(\%$ $\mathrm{CF})$ and protein foods $=40.3227+0.5398(\% \mathrm{CP})$ $+0.4448(\% \mathrm{ENN})+1.4218(\% \mathrm{EE})-0.7007(\%$ $\mathrm{CF})$. The samples were analyzed in triplicate at the Laboratory of Feed Analyses and Animal Nutrition at the State University of Maringá.

\section{Statistical analysis}

The experimental design was completely randomised, with three treatments and ten replications. The results were statistically interpreted using (SAS, 2004) package: Y $i j=\mu+\mathrm{T} i+\mathrm{e} i j$, where $\mathrm{Y} i j=$ dependent variables; $\mathrm{T} i=$ treatment effect and $\mathrm{e} i j=$ residual error.

\section{Results and Discussion}

\section{Methodological aspects}

The eating, ruminating and resting activities were similar $(\mathrm{P}<0.05)$ among time scale (Table 4$)$. Thus, the intake behavior in Nellore bulls finished in feedlot can be assessed every 30 minutes.

Table 4. Intake behavior to according time scale observations of Nellore bulls finished in feedlot.

\begin{tabular}{lcccccccccc}
\hline Intervals* & EAT & RUT & RET & NEP & NRUP & NREP & TET & TRUT & TRET & TCT \\
\hline 5 & 199 & 375 & 865 & $17 \mathrm{a}$ & $19 \mathrm{a}$ & $32 \mathrm{a}$ & $11 \mathrm{a}$ & $19 \mathrm{a}$ & $26 \mathrm{a}$ & 569 \\
10 & 186 & 352 & 901 & $11 \mathrm{~b}$ & $15 \mathrm{~b}$ & $23 \mathrm{~b}$ & $16 \mathrm{~b}$ & $23 \mathrm{~b}$ & $39 \mathrm{~b}$ & 539 \\
15 & 184 & 361 & 894 & $8 \mathrm{~b}$ & $13 \mathrm{~b}$ & $19 \mathrm{~b}$ & $20 \mathrm{~b}$ & $26 \mathrm{~b}$ & $46 \mathrm{~b}$ & 545 \\
20 & 195 & 358 & 886 & $7 \mathrm{~b}$ & $11 \mathrm{~b}$ & $16 \mathrm{~b}$ & $26 \mathrm{~b}$ & $30 \mathrm{~b}$ & $56 \mathrm{~b}$ & 554 \\
25 & 184 & 366 & 872 & $5 \mathrm{~b}$ & $10 \mathrm{~b}$ & $13 \mathrm{~b}$ & $30 \mathrm{~b}$ & $34 \mathrm{~b}$ & $64 \mathrm{~b}$ & 550 \\
30 & 186 & 346 & 906 & $5 \mathrm{~b}$ & $9 \mathrm{~b}$ & $12 \mathrm{~b}$ & $33 \mathrm{~b}$ & $35 \mathrm{~b}$ & $73 \mathrm{~b}$ & 532 \\
\hline${ }^{1} \mathrm{VC}, \%$ & 19.3 & 16.5 & 15.6 & 16.4 & 19.1 & 14.2 & 13.6 & 17.9 & 19.8 & 15.6 \\
\hline
\end{tabular}

Eating time (EAT), ruminating time (RUT), resting time (RET), number of eating period (NEP), number of ruminating period (NRUP), number of resting period (NREP), total eating time (TET), total ruminating time (TRUT), total resting time (TRET) and total chewing time (TCT). ${ }^{1}$ Variation coefficient. ${ }^{*}$ Intervals in minutes. Means followed by different letters in the same column were different $(\mathrm{P}<0.05)$.

Source: Elaboration of the authors.

De Boever et al. (1990) observed that feed intake in cattle occurs more throughout the day, and the eating time varies more when compared with the ruminating and resting time. This could show that 
the discretization of the series scale superior five minutes result in a greater loss of observations and consequently decrease the accuracy of the observations. However, Silva et al. (2005a) evaluated the ingestive behavior in dairy crossbred heifers grazing and concentrate-supplemented and recommend time scale up to 30 minutes to study the daily activities of eating, ruminating and resting. Likewise, Silva et al. (2005b) tested time scales 10, 15, 20, 25 and 30 minutes in Holstein vs. crossbred heifers zebu fed elephant grass silage and cassava and found no differences when compared to the interval of 5 minutes for the activities of eating, ruminating and resting. Those authors reported 30-minutes intervals of observations for such variables. Interval chose to discretize time series, i.e, time spent eating, ruminating and resting should be balance the power to detect changes as activities occur and the accuracy without incurring errors of assessment (FISCHER et al., 2000). Some researchers have been working with different time scales and used five minutes (ÍTAVO et al., 2008; FREITAS et al., 2010), 10 minutes (BREMM et al., 2008) and 60 minutes between observations (BORJA et al., 2009). The ingestive behavior, considering the number of discrete periods of activity, the time scale of observation more than five minutes is used once it better detect the frequency for each daily activity; which would decrease the loss of observations (SILVA et al., 2006). However, this study shows that the record for activities of eating, ruminating and resting can be done at intervals of 30 minutes. The choice for this methodology is reliable; which is a very important factor, since visual observations with shorter intervals time is a process that increases the work for observers.

For the number for eating period (NEP), the number of ruminating period (NRUP) and the number of resting period (NREP) the values of time scales of observations from 10, 15, 20, 25 and 30 minutes were similar $(\mathrm{P}>0.05)$ among them and lower $(\mathrm{P}<0.05)$ than values observed for time scale from 5 minutes (Table 4).
Differently, for the time of eating period (TEP), time of ruminating period time (TRP) and time of resting period time (TREP) the values observed from time scales of 10,15, 20, 25 and 30 minutes were similar $(\mathrm{P}>0.05)$ among them and higher $(\mathrm{P}<0.05)$ for values observed from time scale of 5 minutes (Table 4). The values means for the periods number were underestimated with scales of 10,15 , 20, 25 and 30 minutes, whilst were overestimated for the same periods in time scales.

Such results show that the five minutes time intervals can be used once they determine a lower number of observations losses. While the scale of five minutes for eating period number were harvested 15 observations, on scales of 10, 15, 20, 25 and 30 minutes were harvested eight, seven, five and four observations, respectively. The frequency of observations present such decreasing once the animals change the intervals of eating, ruminating and resting activities several times during the day (PENNING et al., 1995; KILGOUR, 2012). Thus, by increasing the intervals among observations, many of these activities are not recorded. The values observed among the tested intervals indicate that intervals above five minutes cannot be used to study when the aim it is to study the number and time for eating, ruminating and resting activities periods. Likewise, Carvalho et al. (2007) reported that the five-minutes scale was superior to the other ones for it allowed us to more accurately detect the daily frequency spent on each activity. These results were similar to those observed by Silva et al. (2006) revealing that studies are unable to determine the mean time spent eating, ruminating and resting at intervals above 10 minutes. According to Pinheiro et al. (2011a) the five-minute intervals results in less loss in the number of observations in Holstein vs. zebu heifers in feedlot.

The total chewing time (TCT) was similar $(\mathrm{P}>0.05)$ for all ranges of observations time. Likewise, Marques et al. (2008) working on crossbred bulls, aged 18 months on average and 
weigh on average $398 \mathrm{~kg}$, with three diets based on sugar cane and sorghum silage chopped and different levels of concentrate in the base of corn and soybean meal observed no differences among the intervals for the TCT. These results confirm the data observed by Silva et al. (2006) who also found no differences when compared time scales observations between five and 30 minutes in supplemented heifers and heifers in grazing, respectively.

The number of chewing per bolus (NCB), the time of ruminated bolus (TRB), the number of ruminated bolus per day (NRBD) and the number of chewing per day (NCD) were similar $(\mathrm{P}>0.05)$ among the number of observations per turns (Table 5).

Table 5. Intake behavior of Nellore bulls finished in feedlot according to the number of observations per turns.

\begin{tabular}{|c|c|c|c|c|c|c|}
\hline \multirow{2}{*}{ Parameters } & \multicolumn{4}{|c|}{ Observations turns* } & \multirow{2}{*}{$\mathrm{VC}(\%)^{1}$} & \multirow{2}{*}{$\mathrm{P}>\mathrm{F}$} \\
\hline & $4 \mathrm{~S}$ & $3 \mathrm{~S}$ & $2 \mathrm{~S}$ & $1 \mathrm{~S}$ & & \\
\hline $\mathrm{NCB}, \mathrm{n}^{\circ} /$ bolus $^{2}$ & 58.9 & 58.6 & 58.1 & 58.5 & 12.8 & 0.42 \\
\hline $\mathrm{TRB}, \mathrm{sec}^{3}$ & 71.2 & 71.0 & 71.0 & 68.9 & 17.9 & 0.80 \\
\hline NRBD, n ${ }^{\circ}$ day $^{4}$ & 325 & 527 & 332 & 341 & 20.9 & 0.83 \\
\hline NCD, $n^{\circ} /$ day $^{5}$ & 19.132 & 19.146 & 19.181 & 19.621 & 21.1 & 0.97 \\
\hline
\end{tabular}

${ }^{1}$ Variation coefficient, ${ }^{2}$ number of chewing per bolus, ${ }^{3}$ time of ruminated bolus, ${ }^{4}$ number of ruminated bolus per day, ${ }^{5}$ number of chewing per day 5 .

Source: Elaboration of the authors.

Thus, the behavior of those variables could be registered only one turn per day, as the results observed by Pinheiro et al. (2011b) in crossbred heifers (Holstein vs. Zebu) finished in feedlot and fed with different levels of cocoa meal and elephant grass silage addition in the diet. According to Mertens (1994) the fibrous component in the food stimulates rumination in order to reduce particle size and increase ruminal degradation of nutrients. This understanding leads to the conclusion that the similarity with increasing replications comes from the time when this data is collected, since replications are sequentially taken, in the same period of ruminating and consequently the same rumen contents.

\section{Diets effects}

The partial replacing of corn by glycerine $(15 \%$ on a DM) as an energy source, and the addition of functional oils in the diets for bulls had no effect ( $\mathrm{P}>0.05$ ) on eating time (Table 6). However, ruminating time was lower $(\mathrm{P}<0.05)$ to bulls fed GLY diet than to bulls fed CON and GFO diets. Yet, ruminating time was similar between $\mathrm{CON}$ and GFO diets (Table 6). The resting time was similar $(\mathrm{P}>0.05)$ to bulls fed CON and GFO diets and lower $(\mathrm{P}<0.05)$ to bulls fed GLY diet (Table 6) to the bulls fed with two other diets. 
Table 6. Time of eating, ruminating and resting (\% of time) of Nellore bulls finished in feedlot.

\begin{tabular}{|c|c|c|c|c|c|}
\hline \multirow{2}{*}{ Activities } & \multicolumn{3}{|c|}{ Diets } & \multirow{2}{*}{$\mathrm{VC}, \%^{4}$} & \multirow{2}{*}{$\mathrm{P}>\mathrm{F}$} \\
\hline & $\mathrm{CON}^{1}$ & GLY $^{2}$ & $\mathrm{GFO}^{3}$ & & \\
\hline Eating & 13.36 & 13.41 & 14.78 & 25.05 & 0.20 \\
\hline Ruminating & $26.91 \mathrm{a}$ & $22.33 b$ & $28.94 \mathrm{a}$ & 14.47 & 0.05 \\
\hline Resting & $59.73 b$ & $64.26 \mathrm{a}$ & $56.28 \mathrm{~b}$ & 8.41 & 0.05 \\
\hline
\end{tabular}

${ }^{1}$ Control, ${ }^{2}$ Glycerine, ${ }^{3}$ Glycerine + Functional oils. ${ }^{4}$ Variation coefficient. Means followed by different letters in the same column were different $(\mathrm{P}<0.05)$.

Source: Elaboration of the authors.

The ingestive behavior of cattle grazing is characterized by long periods of feeding (from four to 12 hours per day) focusing on early morning and late afternoon (HICKS; OWENS; GILL, 1989; KILGOUR et al., 2012). However, to cattle in feedlot the periods can change from one hour to foods rich in energy to six or more hours to foods with low energy (POLLI et al., 1996; KILGOUR, 2012)

Diet composition change the ingestive behavior in ruminants (STRICKLIN; KAUTZ-SCANAVY, 1984). Differently, the results of this experiment Farias et al. (2012) observed that heifers fed with diets containing glycerine in place of corn required more time for feed intake when compared to animals fed diets without glycerine, since the physical characteristics of glycerine difficult feed intake (ELAM et al., 2008).

The reduced ruminating time of bulls fed with glycerine diet inclusion may have been caused by a reduction in NDF intake, since glycerine does not contain fiber in its composition (Table 1). The fiber content in the diet stimulates rumination of cattle (MERTENS, 1994). On the other hand, the resting time was increased $(\mathrm{P}<0.05)$ for animals fed with GLY diet, since the variables are not exclusive. Thus, the reduction in the ruminating time induces an increase in the resting time. As observed by Bürger et al. (2000) in Holstein calves receiving different concentrated levels (30-90\%), the eating time varied from 115.2 to $295.2 \mathrm{~min} . /$ day, ruminating time from 253.8 to $451.2 \mathrm{~min}$./day and resting time from 655.2 to $1007.4 \mathrm{~min}$./day. These results show that the ruminating time is reduced linearly when the NDF content of the diet is low, as observed in this experiment.

The functional oils added in the diet increased $(\mathrm{P}<0.05)$ ruminating time and, consequently, reduced resting time. Such behavior could be explained by the action of functional oils on microorganisms present in rumen; similar to that of ionophores. The ionophores modulate interaction among rumen microorganisms inhibiting gram-positive bacteria (GOODRICH et al., 1984). Thus, the reduction of the microorganism's population in the rumen requires more ruminating time to complete food digestion (VAN SOEST, 1994).

The number of eating period was similar $(\mathrm{P}>0.05)$ for bulls fed with glycerine inclusion in the diets (GLY and GFO) and superior $(\mathrm{P}<0.05)$ to the bulls fed with CON diet (Table 7). Thus, glycerine addition in the diet increased the number of eating period. However, functional oils addition did not affect the number of eating period. The number of eating period was 17.8 times per day; which may be modified by the diet nature, but, in general, the number for eating period for cattle finished in feedlot ranges from 14 to 20 times per day (BÜRGER et al., 2000). 
Table 7. Numbers of eating (NEP), ruminating (RUP), resting periods (NREP) and durations of eating (DET), ruminating (DRUT) and resting (DRET) time of Nellore bulls finished in feedlot.

\begin{tabular}{|c|c|c|c|c|c|}
\hline \multirow{2}{*}{ Parameters } & \multicolumn{3}{|c|}{ Diets } & \multirow{2}{*}{$\mathrm{CV}, \%^{4}$} & \multirow{2}{*}{$\mathrm{P}>\mathrm{F}$} \\
\hline & $\mathrm{CON}^{1}$ & $\mathrm{GLY}^{2}$ & $\mathrm{GFO}^{3}$ & & \\
\hline NEP, n $\%$ day & $14.55 b$ & $20.20 \mathrm{a}$ & $18.70 \mathrm{a}$ & 14.62 & 0.04 \\
\hline NRUP, n⿳/day & 19.42 & 18.85 & 20.80 & 14.00 & 0.27 \\
\hline NREP, n /day & $28.83 b$ & $35.50 \mathrm{a}$ & $34.30 \mathrm{a}$ & 10.69 & 0.02 \\
\hline DET, min./visit & 13.36 & 9.62 & 11.58 & 22.37 & 0.52 \\
\hline DRUT, min./visit & 20.17 & 17.37 & 20.26 & 17.61 & 0.37 \\
\hline DRET, min./visit & $29.84 \mathrm{a}$ & $26.69 \mathrm{~b}$ & $24.04 \mathrm{~b}$ & 17.28 & 0.06 \\
\hline
\end{tabular}

${ }^{1}$ Control, ${ }^{2}$ Glycerine, ${ }^{3}$ Glycerine + Functional oils. ${ }^{4}$ Variation coefficient. Means followed by different letters in the same line were different $(\mathrm{P}<0.05)$.

Source: Elaboration of the authors.

Glycerine is a colorless, dense, sweet and a stringent product, when it contacts with the animal's mouth and tongue hinders feed intake. Thus, the animal is forced to return several times to feeder to satisfy its hunger. Another theory that could explain such behavior would be the metabolic pathway of glycerine metabolism in cattle. Glycerine is converted to short chain fatty acids by rumen bacteria and when in excess may inhibit feed intake for a short period of time (GARTON; LOUGH; VIOQUE, 1961). The feed intake reduction by propionate infusion into rumen has been documented in literature (BERGEN, 1972; ALLEN, 2000).

The number of ruminating period was similar ( $\mathrm{P}>0.05)$ for bulls fed with three diets, with mean value of 19.7 times per day (Table 7). According to Rabelo et al. (2008) diets with higher NDF determine an increase in number of ruminating period. However, although diets with glycerine inclusion present a lower NDF; the number of ruminating period was similar to that $\mathrm{CON}$ diet (higher fiber).

The number of resting period was similar $(\mathrm{P}>0.05)$ for bulls fed glycerine diets (GLY and GFO) and being higher for bulls fed CON diet (Table7). The number of resting period was 32.7 times per day.

Both corn replaced by glycerine and functional oils addition in the diet did not affect $(\mathrm{P}>0.05)$ duration of eating and ruminating time (Table 7). According to Mertens (1994) the ingestive behavior of cattle changes with food characteristics to keep feed intake and production levels. Those authors noted, however, that the adaptability of capacity is limited. Increasing the fiber supply did not increase the ruminating time in more than eight or nine hours per day.

The duration of resting period was superior $(\mathrm{P}<0.05)$ for bulls fed CON diet in relation to the bulls fed with GLY and GFO diets (Table 7), with mean value of 26.9 minutes per day. Values close to those were observed also by Pinheiro et al. (2011b) in crossbred Holstein $v s$. Zebu cows fed diets with 4 levels of inclusion of cassava bagasse $(0,5,10$ and $15 \%$ on a DM) with a mean of 25 minutes per day for each resting period.

The number of chewed bolus and the mean number of ruminating time (second per bolus) were similar $(\mathrm{P}>0.05)$ among bulls from three diets (Table $8)$. The mean values of 58.9 chewing per bolus and 71.2 seconds per ruminated bolus, respectively, were observed. 
Table 8. Number of chewed bolus (NCB), time of ruminated bolus (TRB), ruminated bolus day (RBD), number of chewing per day (NCD) and time of total chewing (TTC) of Nellore bulls finished in feedlot.

\begin{tabular}{|c|c|c|c|c|c|}
\hline \multirow{2}{*}{ Activities } & \multicolumn{3}{|c|}{ Diets } & \multirow{2}{*}{$\mathrm{CV}, \%^{4}$} & \multirow{2}{*}{$\mathrm{P}>\mathrm{F}$} \\
\hline & $\mathrm{CON}^{1}$ & $\mathrm{GLY}^{2}$ & $\mathrm{GFO}^{3}$ & & \\
\hline $\mathrm{NCB}, \mathrm{n}^{\circ} /$ bolus & 60 & 58 & 58 & 12.34 & 0.56 \\
\hline TBR, seg/bolus & 74 & 69 & 71 & 22.89 & 0.73 \\
\hline $\mathrm{RBD}, \mathrm{n}^{\mathrm{o}} / \mathrm{day}$ & $328 \mathrm{ab}$ & $286 b$ & $360 \mathrm{a}$ & 20.05 & 0.04 \\
\hline $\mathrm{NCD}, \mathrm{n}^{\circ}$ day & $19.75 \mathrm{ab}$ & $16.65 b$ & $20.99 \mathrm{a}$ & 17.37 & 0.03 \\
\hline TTC, min./day & $569 \mathrm{ab}$ & $512 \mathrm{~b}$ & $626 a$ & 17.22 & 0.03 \\
\hline
\end{tabular}

${ }^{1}$ Control, ${ }^{2}$ Glycerine, ${ }^{3}$ Glycerine + Functional oils. ${ }^{4}$ Variation coefficient. Means followed by different letters in the same line were different $(\mathrm{P}<0.05)$.

Source: Elaboration of the authors.

The number of chewed bolus per day and the time of ruminating bolus vary according to diet, sex and age. Bürger et al. (2000) observed that the number of chewed bolus per day changed from 51.5 to 76.1 times per bolus in dairy cows. Polli et al. (1996) working with different roughages sources (corn silage or sugar cane) did not find differences for number of chewed bolus per day (55 times) and the time of ruminating bolus ( 55 seconds). Likewise, several authors found no differences for number of chewing per bolus ruminated in lactating cows and heifers finished in feedlot and fed with different diets. The observed values were close to 52 chewing per bolus and 46 seconds per each ruminated bolus (MENDONÇA et al., 2004; MENDES NETO et al., 2007). Those published data show that such parameters exhibit great variation depending on the various factors that can influence these variables.

Replacing corn by glycerine in the diets did not affect $(\mathrm{P}>0.05)$ the number of ruminated bolus per day, the number of chewing per day or the time of total chewing by bulls (Table 8 ). However, for the GFO diet the number of ruminated bolus per day, number of chewing per day and time of total chewing by bulls were higher $(\mathrm{P}<0.05)$ than what GLY diets presented. The value mean for the number of ruminated bolus per day was 324. Likewise, Beauchemin and Iwaasa (1993) observed from 350 to 397 ruminated bolus per day in Hereford heifers reared in pasture; which is close to the number found in this study.

The mean value for the number of chewing per day was 19.133 times. These values were lower than what observed by Pinheiro et al. (2011a) in crossbred heifers (Holsteins vs. Zebu) dairy initially aging 13 months old and weighing $166 \mathrm{~kg}$ finished in feedlot and fed with babassu meal and grass elephant silage. According to Forbes (1988) the ruminants may modify one or more of their ingestive behavior activities in order to minimize the effects of different dietary conditions, thus meeting their nutritional requirements for maintenance and growing.

The time of total chewing is the sum of eating time and the ruminating time during the 24 hourobservation, which showed an average of 569 minutes per day. Macleod et al. (1994) observed 603 minutes per day for chewing in cattle finished in feedlot. The value mean of total chewing time changes from 368 to 745 minutes as shows by Bürger et al. (2000).

\section{Conclusions}

Both partial replacing of corn by glycerine and functional oils addition in the diets did not affect the time spent feeding; however, they increase the number of daily periods for this activity in Nellore cattle in feedlot. Animals fed diets with corn 
partially replaced and functional oils ruminated for a longer time. The observations for total times of feeding, ruminating and resting activities can be performed through an interval of 30 minutes. For the discretization of time series of ingestive behavior, it is recommended to scale five minutes between observations. To study aspects of ingestive behavior of bulls in feedlot only one observation per animal may be performed at only one turns of observation.

\section{References}

ALBRIGHT, J. L. Nutrition, feeding and calves: feeding behaviour of dairy cattle. Journal of Dairy Science, Champaign, v. 76, n. 2, p. 485-498, 1993.

ALLEN, M. S. Effects of diet on short-term regulation of feed intake by lactating dairy cattle. Journal of Dairy Science, Champaign, v. 83, n. 7, p. 1598-1624, 2000.

ASSOCIATION OF OFFICIAL ANALYTICAL CHEMISTS - AOAC. Official methods of analysis. Arlington: AOAC International, 1998.

BEAUCHEMIN, K. A.; IWAASA, A. D. Eating and ruminating activities of cattle fed alfalfa or orchard-grass harvested at two stages of maturity. Canadian Journal of Animal Science, Ottawa, v. 73, n. 1, p. 79-88, 1993.

BENCHAAR, C.; CALSAMIGLIA, S.; CHAVES, A. V.; FRASER, G. R.; COLOMBATTO, D.; MCALLISTER, T. A.; BEAUCHEMIN, K. A. A review of plant-derived essential oils in ruminant nutrition and production. Animal Feed Science and Technology, Amsterdan, v. 145, n. 1-4, p. 209-228, 2008.

BERGEN, W. G. Rumen osmolality as a factor in feed intake control of sheep. Journal of Animal Science, Champaign, v. 34, n. 6, p. 1054-1060, 1972.

BORJA, M. S.; GARCEZ NETO, A. F.; OLIVEIRA, R. L.; LIMA, L. S.; BAGALDO, A. R.; BARBOSA, L. P.; FARIA, E. F. S. Óleo de licuri no concentrado administrado a vacas Holandesas X Zebu, sobre o comportamento ingestivo e conforto térmico. Revista Brasileira de Saúde e Produção Animal, Salvador, v. 10, n. 2, p. 344-355, 2009.

BREMM, C.; ROCHA, M. G.; FREITAS, F. K.; MACARI, S.; ELEJALDE, D. A. G.; ROSO, D. Comportamento ingestivo de novilhas de corte submetidas a estratégias de suplementação em pastagens de aveia e azevém. Revista Brasileira de Zootecnia, Viçosa, v. 37, n. 7, p. 1161-1167, 2008.
BÜRGER, P. J.; PEREIRA, J. C.; QUEIROZ, A. C.; COELHO, J. F.; AGOSTINI, P. S.; VALADARES FILHO, S. C.; CECON, P. R.; CASALI, A. D. P. Comportamento ingestivo em bezerros holandeses alimentados com dietas contendo diferentes níveis de concentrado. Revista Brasileira de Zootecnia, Viçosa, MG, v. 29, n. 1, p. 236-242, 2000.

BURT, S. Essential oils: their antibacterial properties and potential applications in foods - a review. International Journal of Food Microbiology, v. 94, n. 3, p. 223-253, jan. 2004.

CALSAMIGLIA, S.; BUSQUET, M.; CARDOZO, P. W.; CASTILlEJOS, L.; FERRET, A. Invited review: essential oils as modifiers of rumen microbial fermentation. Journal of Dairy Science, Champaign, v. 90, n. 6, p. 2580-2595, 2007.

CARVALHO, G. G. P.; PIRES, A. J. V.; SILVA, H. G. O.; VELOSO, C. M.; SILVA, R. R. Aspectos metodológicos do comportamento ingestivo de cabras lactantes alimentadas com farelo de cacau e torta de dendê. Revista Brasileira de Zootecnia, Viçosa, v. 36, n. 1, p. 103-110, 2007.

CHUNG, Y. H.; RICO, D. E.; MARTINEZ, C. M.; CASSIDY, T. W.; NOIROT, V.; AMES, A.; VARGA, G. A. Effects of feeding dry glycerin to early postpartum Holstein dairy cows on lactational performance and metabolic profiles. Journal of Dairy Science, Champaign, v. 90, n. 12, p. 5682-5691, 2007.

COUNCIL FOR INTERNATIONAL ORGANIZATIONS OF MEDICAL SERVICES - CIOMS/OMS. International guiding principles for biomedical research involving animals. WHO Distribution and sales service, 1211 Geneva 27, Switzerland, 1985.

DADO, R. G.; ALLEN, M. S. Intake limitations, feeding behavior, and rumen function of cows challenged with rumen fill from dietary or inert bulk. Journal of Dairy Science, Champaign, v. 78, n. 1, p. 119-133, 1995.

De BOEVER, J. L.; ANDRIES, J. I.; De BRABANDER, D. L.; COTTYN, B. G.; BUYSSE, F. X. Chewing activity of ruminants as a measure of physical structure a review of factors affecting it. Animal Feed Science and Technology, Amsterdan, v. 27, n. 4, p. 281-291, 1990.

EIRAS, C. E.; BARBOSA, L. P.; MARQUES, J. A.; ARAÚJO, F. L.; LIMA, B. S.; ZAWADZKI, F.; PEROTTO, D.; PRADO, I. N. Glycerine levels in the diets of crossbred bulls finished in feedlot: apparent digestibility, feed intake and animal performance. Animal Feed Science and Technology, Amsterdan, 2014, in press. 
ELAM, N. A.; ENG, K. S.; BECHTEL, B.; HARRIS, J. M.; CROCKER, R. Glycerol from biodiesel production: considerations for feedlot diets. Proceedings of the Southwest Nutrition Conference, New Mexico, v. 1, n. 1, p. 1-13, 2008.

FOOD AND AGRICULTURAL POLICY RESEARCH INSTITUTE - FAPRI. Food and agricultural policy research institute. Ames, IA, 20/01/2013, 2012. Disponível em: <http://www.fapri.iastate.edu/tools/ outlook.aspx>. Acesso em: 10 ju. 2014.

FARIAS, M. S.; SILVA, R. R.; ZAWADZKI, F.; EIRAS, C. E.; LIMA, B. S.; PRADO, I. N. Glycerin levels for crossbred heifers supplemented in pasture: intake behavior. Acta Scientiarum. Animal Sciences, Maringá, v. 34, n. 1, p. 63-69, 2012.

FISCHER, V.; DUTILLEUL, P.; DESWYSEN, A. G.; DÈSPRES, L.; LOBATO, J. F. P. Aplicação de probabilidades de transição de estado dependentes do tempo na análise quantitativa do comportamento ingestivo de ovinos. Parte I. Revista Brasileira de Zootecnia, Viçosa, v. 29, n. 6, p. 1811-1820, 2000.

FORBES, T. D. A. Researching the plant-animal interface: the investigation of ingestive behavior in grazing animals. Journal of Animal Science, Champaign, v. 66, n. 9 , p. $2369-2379,1988$.

FREITAS, L. S.; SILVA, J. H. S.; SEGABINAZZI, L. R.; SILVA, V. S.; ALVES FILHO, D. C.; BRONDANI, I. L. Substituição da silagem de milho por silagem de girassol na dieta de novilhos em confinamento: comportamento ingestivo. Revista Brasileira de Zootecnia, Viçosa, v. 39, n. 1, p. 225-232, 2010.

GARTON, G. A.; LOUGH, A. K.; VIOQUE, E. Glyceride hydrolysis and glycerol fermentation by sheep rumen contents. Journal of General Microbiology, Abeereen, v. 25, n. 2, p. 215-225, 1961.

GARY, L. A.; SHERRITT, G. W.; HALE, E. B. Behavior of Charolais cattle on pasture. Journal of Animal Science, Champaign, v. 30, n. 2, p. 203-206, 1970.

GOFF, J. P.; HORST, R. L. Oral glycerol as an aid in the treatment of ketosis/fatty liver complex. Journal of Dairy Science, Champaign, v. 84, p. 153, 2001.

GOODRICH, R. D.; GARRETT, J. E.; GAST, D. R.; KIRICK, M. A.; LARSON, D. A.; MEISKE, J. C. Influence of monensin on the performance of cattle. Journal of Animal Science, Champaign, v. 58, n. 6, p. 1484-1498, 1984.

HICKS, R. B.; OWENS, F. N.; GILL, D. R. Behavioral patterns of feedlot steers. Oklahoma State University Annual Science Research Report, Oklahoma, v. 1, n. 127, p. 94-105, 1989.
HOCQUETTE, J. F.; BOTREAU, R.; PICARD, B.; JACQUET, A.; PETHICK, D. W.; SCOLLAN, N. D. Opportunities for predicting and manipulating beef quality. Meat Science, Amsterdan, v. 92, n. 3, p. 197-209, 2012.

ÍTAVO, L. C. V.; SOUZA, S. R. M. B. O.; RÍMOLI, J.; ÍTAVO, C. C. B. F.; DIAS, A. M. Comportamento ingestivo diurno de bovinos em pastejo contínuo e rotacionado. Archivos de Zootecnia, Cordóba, v. 57, n. 217, p. 43-52, 2008.

ITO, R. H.; PRADO, I. N.; VISENTAINER, J. V.; PRADO, R. M.; FUGITA, C. A.; PIRES, M. C. O. Carcass characteristics, chemical and fatty acid composition of Longissimus muscle of Purunã bulls slaughtered at 18 or 24 months of age. Acta Scientiarum.Animal Sciences, Maringá, v. 32, n. 3, p. 299-307, 2010.

KAZAMA，R.; ZEOULA，L. M.; PRADO, I. N.; SILVA, D. C.; DUCATTI, T.; MATSUSHITA, M. Características quantitativas e qualitativas da carcaça de novilhas alimentadas com diferentes fontes energéticas em dietas à base de cascas de algodão e de soja. Revista Brasileira de Zootecnia, Viçosa, v. 37, n. 2, p. 350-357, 2008.

KEARL, L. C. Nutrient requirements of ruminants in developing countries. Utah, UT: International Feedstuffs Institute, Utah Agricultural Experiment Station, Utah State University, 1982. 382 p.

KILGOUR, R. J. In pursuit of normal: a review of the behaviour of cattle at pasture. Applied Animal Behaviour Science, Amsterdan, v. 138, n. 1-2, p. 1-11, 2012.

KREHBIEL, C. R. Ruminal and physiological metabolism of glycerin. Journal of Animal Science, Champaign, v. E86, p. 392, 2008. Supplement.

LEE, S. Y.; LEE, S. M.; CHO, Y. B.; KAM, D. K.; LEE, S. C.; KIM, C. H.; SEO, S. Glycerol as a feed supplement for ruminants: In vitro fermentation characteristics and methane production. Animal Feed Science and Technology, Amsterdan, v. 166, n. 1, p. 269-274, 2011.

MACH, N.; BACH, A.; DEVANT, M. Effects of crude glycerin supplementation on performance and meat quality of Holstein bulls fed high-concentrate diets. Journal of Animal Science, Champaign, v. 87, n. 2, p. 632-638, 2009.

MACLEOD, G. K.; COLUCCI, P. E.; MOORE, A. D.; GRIEVE, D. G.; LEWIS, N. The effects of feeding frequency of concentrates and feeding sequence of hay on eating behavior, ruminal environment and milk production in dairy cows. Canadian Journal of Animal Science, Ottawa, v. 74, n. 1, p. 103-113, 1994. 
MARQUES, J. A.; PINTO, A. P. J. S.; ABRAHÃO, J.; NASCIMENTO, W. G. Intervalo de tempo entre observações para avaliação do comportamento ingestivo de tourinhos em confinamento. Semina: Ciências Agrárias, Londrina, v. 29, n. 4, p. 955-960, 2008.

MENDES NETO, J.; CAMPOS, J. M. S.; VALADARES FILHO, S. C.; LANA, R. P.; QUEIROZ, A. C.; EUCLYDES, R. F. Comportamento ingestivo de novilhas leiteiras alimentadas com polpa cítrica em substituição ao feno de capim-tifton 85. Revista Brasileira de Zootecnia, Viçosa, v. 36, n. 3, p. 618-625, 2007.

MENDONÇA, S. S.; CAMPOS, J. M. S.; VALADARES FILHO, S. C.; VALADARES, R. F. D.; SOARES, C. A.; LANA, R. P.; QUEIROZ, A. C.; ASSIS, A. J.; PEREIRA, M. L. A. Comportamento ingestivo de vacas leiteiras alimentadas com dietas à base de cana-de-açúcar ou silagem de milho. Revista Brasileira de Zootecnia, Viçosa, v. 33, n. 3, p. 723-728, 2004.

MERTENS, D. R. Regulation of forage intake. In: FAHEY, J. R. (Ed.). Forage quality, evaluation, and utilization. Madison, WI, USA: Amer Society of Agronomy, 1994. p. 450-493.

Gravimetric determination of amylase-treated neutral detergent fiber in feeds with refluxing in beakers or crucibles: collaborative study. Journal of $A O A C$ International, local, v. 85, n. 6, p. 1217-1240, 2002.

MISSIO, R. L.; BRONDANI, I. L.; ALVES FILHO, D. C.; SILVEIRA, M. F.; FREITAS, L. S.; RESTLE, J. Comportamento ingestivo de tourinhos terminados em confinamento, alimentados com diferentes níveis de concentrado na dieta. Revista Brasileira de Zootecnia, Viçosa, v. 39, n. 7, p. 1571-1578, 2010.

MORRIS, L. J. The mechanism of ricinoleic acid biosynthesis in Ricinus communis seeds. Biochemical and Biophysical Research Communications, London, v. 29, n. 3, p. 311-315, 1967.

NAUGHTON, F. C. Castor oil. In: NAUGHTON, F. C. (Ed.). Kirk-Othmer encyclopedia of chemical technology. New York: John Wiley \& Sons, 2000. p. 866.

NOVAK, A.; CLARK, G.; DUPUY, H. Antimicrobial activity of some ricinoleic acid oleic acid derivatives. Journal of the American Oil Chemists' Society, Berlim, v. 38, n. 6, p. 321-324, 1961.

NATIONAL RESEARCH COUNCIL- NRC. Nutrient requirements of beef cattle. $7^{\text {th }}$ ed. Washington, DC: Natl. Acad. Press, 2000. 276 p.

OFFICIAL JOURNAL OF THE EUROPEAN UNION. Regulation (EC) $\mathrm{N}^{\circ} 1831 / 2003$ of the European parliament and of the council of 22 September 2003 on additives for use in animal nutrition. Europe: OJEU, 2003. p. 268.

PENNING, P. D.; PARSONS, A. J.; ORR, R. J.; HARVEY, A.; CHAMPION, R. A. Intake and behaviour responses by sheep, in different physiological states, when grazing monocultures of grass or white clover. Applied Animal Behaviour Science, Amsterdan, v. 45, n. 1, p. 63-78, 1995.

PINHEIRO, A. A.; VELOSO, C. M.; SANTANA JÚNIOR, H. A.; LIMA, L. P.; SILVA, F. F.; SILVA, R. R.; MENDES, F. B. M.; OLIVEIRA, H. C.; CARDOSO, E. O. Intervalos de observações com diferentes escalas de tempo no comportamento ingestivo de vacas leiteiras confinadas. Revista Brasileira de Saúde e Produção Animal, Salvador, v. 12, n. 3, p. 670-679, 2011a.

PINHEIRO, A. A.; VELOSO, C. M.; SANTANA JÚNIOR, H. A.; ROCHA NETO, A. L.; SILVA, R. R.; LIMA, F. B. M.; OLIVEIRA, L. N.; AZEVEDO, S. T.; CECATO, U. Avaliação dos intervalos e números de observações no comportamento ingestivo de novilhas leiteiras confinadas. Revista Brasileira de Saúde e Produção Animal, Salvador, v. 12, n. 2, p. 480-490, 2011 b.

POLLI, V. A.; RESTLE, J.; SENNA, D. B.; ALMEIDA, S. R. S. Aspectos relativos à ruminação de bovinos $\mathrm{e}$ bubalinos em regime de confinamento. Revista Brasileira de Zootecnia, Viçosa, MG, v. 25, n. 5, p. 987-993, 1996.

RABELO, M. M. A.; PIRES, A. V.; SUSIN, I.; MENDES, C. Q.; OLIVEIRA JÚNIOR, R. C.; GENTIL, R. S.; FERREIRA, E. M. Avaliação do efeito do bagaço de cana-de-açúcar in natura obtido por dois métodos sobre o desempenho eo comportamento ingestivo de bovinos de corte. Arquivo Brasileiro de Medicina Veterinária e Zootecnia, Belo Horizonte, v. 60, n. 3, p. 698-704, 2008.

RUSSELL, J. B.; STROBEL, H. J. Effect of ionophores on ruminal fermentation. Applied and Environmental Microbiology, Amsterdam, v. 55, n. 1, p. 1-6, 1989.

STATISTICAL ANALYSIS SYSTEM INSTITUTE SAS. SAS/STAT User guide, Version 9.1.2. Cary, NC, USA: SAS Institute Inc, 2004.

SHIN, S. Y.; KIM, H. R.; KANG, S. C. Antibacterial activity of various hydroxy fatty acids bioconverted by Pseudomonas aeruginosa PR3. Agricultural Chemistry and Biotechnologye, Korea, v. 47, n. 4, p. 205-208, 2004.

SILVA, R. R.; CARVALHO, P. C. F.; MAGALHÃES, F.F.; PRADO, I. N.; FRANCO, S. L.; VELOSO, C. M.; CHAVES, M. A.; PANIZZA, J. C. J. Comportamento ingestivo de novilhas mestiças de holandês em pastejo. Archivos de Zootecnia, Cordóba, v. 54, n. 5, p. 63-74, 2005a. 
SILVA, R. R.; SILVA, F. F.; CARVALHO, G. G. P.; FRANCO, I. L.; VELOSO, C. M.; CHAVES, M. A.; BONOMO, P.; PRADO, I. N.; ALMEIDA, V. S. Comportamento ingestivo de novilhas mestiças de Holandês x Zebu confinadas. Archivos de Zootecnia, Cordóba, v. 54, n. 205, p. 75-85, 2005b.

SILVA, R. R.; SILVA, F. F.; PRADO, I. N.; CARVALHO, G. G. P.; FRANCO, I. L.; ALMEIDA, I. C. C.; CARDOSO, C. P.; RIBEIRO, M. H. S. Comportamento ingestivo de bovinos. Aspectos metodológicos. Archivos de Zootecnia, Cordóba, v. 55, n. 211, p. 293-296, 2006.

SNIFFEN, C. J.; O'CONNOR, J. D.; VAN SOEST, P. J.; FOX, D. G.; RUSSELL, J. B. A net carbohydrate and protein system for evaluating cattle diets: II. Carbohydrate and protein availability. Journal of Animal Science, Champaign, v. 70, n. 11, p. 3562-77, 1992.

SOUZA, S.; ÍTAVO, L. C. V.; RÍMOLI, J.; ÍTAVO, C.; DIAS, A. M. Comportamento ingestivo diurno de bovinos em confinamento e em pastagens. Archivos de Zootecnia, Cordóba, v. 56, n. 213, p. 67-70, 2007.
STRICKLIN, W. R.; KAUTZ-SCANAVY, C. C. The role of behavior in cattle production: a review of research. Applied Animal Ethology, Amsterdam, v. 11, n. 4, p. 359390, 1984.

TREVISAN, M. T. S.; PFUNDSTEIN, B.; HAUBNER, R.; WÜRTELE, G.; SPIEGELHALDER, B.; BARTSCH, H.; OWEN, R. W. Characterization of alkyl phenols in cashew (Anacardium occidentale) products and assay of their antioxidant capacity. Food and Chemical Toxicology, Amsterdam, v. 44, n. 2, p. 188-197, 2006.

VAN SOEST, P. J. Nutritional ecology of the ruminant. Ithaca, NY: Cornell University Press, 1994. 476 p.

VAN SOEST, P. J.; ROBERTSON, J. B.; LEWIS, B. A. Methods for dietary fiber, neutral detergent fiber, and nonstarch polysaccharides in relation to animal nutrition. Journal of Dairy Science, Champaign, v. 74, n. 10, p. 3583-3597, 1991.

ZHANG, W.; XIAO, S.; SAMARAWEERA, H.; LEE, E. J.; AHN, D. U. Improving functional value of meat products. Meat Science, Amsterdan, v. 86, n. 1, p. 15-31, 2010. 
